Article

\title{
In Waze We Trust: Algorithmic Governance of the Public Sphere
}

\author{
Shenja van der Graaf \\ Studies in Media, Innovation and Technology, imec Brussels, Vrije Universiteit Brussel, 1050 Brussels, Belgium; \\ E-Mail: shenja.vandergraaf@imec.be
}

Submitted: 4 July 2018 | Accepted: 8 October 2018 | Published: 21 December 2018

\begin{abstract}
This article explores the current 'place' of e-government in realizing public value in the context of what seems to be an emerging platform urbanism. It highlights a complex platform-based urban ecosystem encompassing private and public organisations and citizens. This 'mainstreaming' of e-government practices puts demands on cities and governments to reconsider their own role in 'city making' so as to achieve meaningful public oversight. The point of departure is the operationalization of this 'place' by conceptualizing participation and (multi-sided) platformisation as a framework to draw attention to the dynamic domain of e-governance where shifts can be seen in market structures, infrastructures, and changing forms of governance, and which may challenge the public interest. This is illustrated by an exploration of the social traffic and navigation application Waze.
\end{abstract}

\section{Keywords}

e-governance; participation; platforms; public value; social navigation application; smart city; Waze

\section{Issue}

This article is part of the issue "E-Government and Smart Cities: Theoretical Reflections and Case Studies", edited Peter Mechant (Ghent University, Belgium) and Nils Walravens (Vrije Universiteit Brussel, Belgium).

(C) 2018 by the author; licensee Cogitatio (Lisbon, Portugal). This article is licensed under a Creative Commons Attribution 4.0 International License (CC BY).

\section{Introduction}

With the omnipresence of pervasive and always-on (mobile) computing technologies and absence of ethernet cables and dial-up modems, 'the Internet is everywhere, all the time.' Since people no longer need to consciously connect to the Internet (until it breaks down), the idea of the Internet as an infrastructure has receded into the background of everyday life (Driscoll, 2016). 'The Internet' has been overhauled by other terms and metaphors, such as convergence (Jenkins, 2006) and cloud (Hu, 2016), and now something called 'the platform' has taken centre stage. In conveying an ideological imaginary associated with the reconfiguration of production, consumption, distribution and monetization of cultural goods and services (Nieborg \& Poell, 2018), the platform is currently a powerful metaphor for the way contemporary society organizes and understands itself. Understanding the dynamics and influence of platforms over the public sphere-particularly, with a recent focus to 'smarten up' our cities-has become an important task, warranting an investigation into what role platforms and closely connected terms such as algorithms and artificial intelligence truly play (Komninos \& Mora, 2018; cf. Finn, 2017). Sensors, cameras, smartphones, and so forth operate in a platform-based ecosystem and can reveal, map, monitor, and process huge volumes of data which, if shared, allow all kinds of stakeholders including citizens, to rethink the action modalities, the interventions, and the very policies of many subjects in our everyday life (cf. Bernardi, 2015). Moreover, as platforms develop and algorithms increase in power and complexity-in their various manifestations deeply embedded into the systems and infrastructures that underpin the built environment and governance dynamics-, new service models, new forms of reciprocity and public management are emerging to tap value from these growing assets. While some hail these developments, others point to the possible risks and detrimental effects for individuals and for society at large. In particular, as many of our everyday activities are increasingly becoming automated, delegation of decision-making and governance to mere algorithmic 
engines of smart city infrastructures is not clear-cut. It involves the risk of losing sight of critical attention to social and environmental processes including public values and sustainability efforts (Caplan \& boyd, 2016; Gillespie, 2018; Overton, 2017; van Dijck, Poell, \& de Waal, 2016; Zambonelli, Salim, Loke, De Meuter, \& Kanhere, 2018). In addition, automated processes and supporting platforms tend not to be stand-alone but are laboriously connected (and ever-expanding) with other platforms, by way of facilitating access to portal sites via social network logins, or creating tailored advertisements from one site to the next, or using recommendation systems via digital data footprints.

Information and communication technologies (ICT) and services can thus be seen to elevate and facilitate how cities, in general and in the public sphere, in particular, are understood and planned, the way urban services and utilities are managed, and how we experience and live our urban lives (Mattern, 2017). By and large, cities seem to play catch-up, learning how to navigate, process, manage and negotiate the real-time (big) data flows and disruptive business models stemming from new digital infrastructure and services as major drivers of urban change (or, platform capitalism; Srnicek, 2017) by, in the West, platform companies Google, Apple, Facebook, Amazon and Microsoft as well as 'variants' such as Uber and Airbnb. Today, this significance of platforms (and data) in our everyday communication, social, and economic life fuels many questions such as Who owns platforms with what implications? Who generates data collected via platforms? Is a platform public or private? How do different and diverse actors get access to platforms? How are platforms protected and regulated? These and other questions, guided by conceptualizing terms like algorithmic accountability, augmented civic space, and platformisation, reflect an important focal point for academics in developing critical accounts of the every-increasing role of ICT in our society. Particularly, communication and media scholars can be seen to focus on the contemporary position of platforms and how platforms are implicated in the structures that shape everyday life and cities as a whole. In doing so, they seek to produce insights into the ways cities growingly rely upon and push back against platform-based communication and practices characterized by market and nonmarket relations as well as a so-called 'platform dependency' (cf. Nieborg \& Poell, 2018). The idea of a private, commercial public sphere may not be new, yet what seems to be at stake is a meaningful public oversight over the coevolution of social (community/public) and business (commerce/private) developments, operations and implications for cities in the realm of platforms (cf. Van Couvering, 2017). The definite blurring of commercial, government as well as citizen interests seems to be indicative of the way public space is 'translated' into 'code', and how 'code' is seen to 'reshape' the public sphere, thereby alluding to a kind of 'platform urbanism' that increasingly underpins what it means to live in cities (Kitchin \& Dodge, 2011; van der Graaf \& Ballon, 2018). In fact, nowadays, many cities across the globe can be seen to expand their efforts to improve their cities by becoming 'more digitalized', 'more intelligent', and 'smarter', associated with the smarter government movements. The current shifting of the conceptual and technological status quo warrants an investigation into the role of e-government vis-à-vis this smart city imaginary which, in turn, draws attention to public value. The reason for this is that, 'the work' of egovernance has always tended to be somewhat problematic and now, in this set-up, understood as primarily a government-led initiative is even more at risk as arguably city governments seem to be losing control of their capability to 'design their city'. Thus, the objective here is to discuss the need for a more holistic approach that calls for a framework to evaluate the effective 'smartness' of e-governance initiatives in an increasingly complex multi-stakeholder platform-based urban ecosystem (cf. Castelnovo, Misuraca, \& Savoldelli, 2016).

More specifically, over the past twenty years, the management of government and governance practices, through the use of ICT, have rendered government more accessible to citizens and facilitate interlinking between citizens, civil society and market players, and government institutions. The objective of e-government lies herein to maximize the benefits for all stakeholders (United Nations, 2014). While the adoption, scope and advancement of e-government technologies have expanded widely, the outcomes tend to be directed at the achievement of efficiency and service effectiveness benefits (such as cost cutting and optimizing internal organization) rather than public service delivery. Actually, studies point to an overall minimal impact of e-government on public value (Rose, Persson, \& Heeager, 2015), as well as a robust understanding of the factors that government agencies put forward towards the delivery of public value vis-à-vis user reception and engagement (Meijer \& Bekkers, 2015). Furthermore, the conceptualization of public value is somewhat contested and cannot be easily distilled from the literature, however, the term seems to be deployed as an assessment tool for the performance of public services, involves co-creation between multiple stakeholders, such as governments and user communities, and it necessitates an increase in services that enrich democratic, public values (Bryant, 2007; Nugent, 2001; Rawahi, Coombs, \& Doherty, 2016). In this view, a call for a future-orientated perspective can be heard, putting the urge of sustainability forward (Larsson \& Grönlund, 2016).

The discourse on smart cities, however, has been having a tendency to focus on rankings of technological capability, paying insufficient attention to alternative, minority and informal, or even more 'human' views. The aim of designing for smart cities is thus to connect between the conceptual, physical, and technological status quo. And this is exactly where the challenge lies. The predominant provider's perspective has tended to impose 
a rather narrow (top-down and techno-centric) view of 'what' and 'who' the city is for, and is at the heart of power struggles. And now with the interest in and uptake of a seeming 'platform urbanism' it is time to look at the intersection of e-governance objectives, public value and smart city service designs and ask Whose version is it? In order to establish public oversight attention needs to shift to the platform arrangements so that, at a minimum, governments get a clear understanding of the 'black box' that platform(-ecosystem) innovation entails and may impact on broad public interest goals (Mansell, 2016), so cities can make better informed decisions to see what their 'place' is in it. In other words, there is a need to understand the 'reconfiguration' of cities as a multi-stakeholder place through ICT (or, platforms); both in terms of the city's governance and representation, on the one hand, and its mediated production, consumption and experience, on the other hand (cf. Georgiou, 2010).

This article explores, against this backdrop, the current 'place' of e-government in realizing public value in the context of what seems to be an emerging 'platform urbanism.' It highlights a complex platform-based ecosystem encompassing private and public organisations and citizens. This 'mainstreaming' of e-government practices via platform services demands cities and governments to reconsider their own role in 'city making' so as to achieve meaningful public oversight and anticipate and mitigate (un)intended consequences in the long-run. The point of departure is then the operationalization of this 'place' by conceptualizing participation and (multi-sided) platformisation as a framework to draw attention to the dynamic domain of e-governance where shifts can be seen in market structures, infrastructures, and changing forms of governance, and which may challenge the public interest. This is further illustrated by an exploration of the systemic features of (social) traffic and navigation application Waze ${ }^{1}$. Some concluding remarks stressing the need for further insights to develop an effective assessment approach are offered in the last section.

\section{Emerging Spaces of E-Governance}

With persistent developments in ICT as well as a preoccupation with 'smart cities', the interest in e-governance is thriving (Rawahi et al., 2016). The term is used for the management of government and governance practices through the use of ICT and is aimed at making government more accessible to citizens and other stakeholders. In addition, by its material infrastructure it also contributes to the promise in support of the democratic process, such as in terms of allowing for a more participatory means for citizen engagement and consultation, pointing to a move from adoption to adaptation (Bryant, 2007; cf. Habermas, 1991). Conceptions of e- governance tend to understand technological systems and tools as the enablers of a new type of governance that are said to make government more efficient as well as more democratic (and which may lead to a kind of e-democracy)-often described in terms of 'complementary', or in a stronger outlook, 'evolutionary' (Fisher, 2012). The latter has been found to encompass four stages, that is, 'digitization' (where the governmental agency implements and experiments with the technology), 'transformation' (the technology is deployed for re-engineering and streamlining internal processes), 'engagement' (focus on expansion so as to communicate and engage with external stakeholders), and 'customization' (customization of services vis-à-vis the needs of specific communities, citizens, and so forth) (Janowski, $2015,2016)$. While a shift in focus can be detected in the literature on e-government, from a 'technologicaloperational' orientation, to a 'managerial-organizational' orientation, and today a 'political-institutional' orientation (where some emphasis can be distilled on transparency and open government) (Savoldelli, Codagnone, \& Misuraca, 2014). It is in this perspective, where digital public services have the potential to actively engage with citizens and cater to their specific needs, that e-government is said to have the opportunity to serve as an explicit mechanism to underpin the delivery of public value (Rawahi et al., 2016). Such discourse seems to presume that e-governance is in essence a government-led initiative, instigated by the necessity to keep pace with digital developments and to improve governance practices and services. However, this obscures the conflation of technology and politics that seems to be merely legitimizing shifts in the balance of power between states and markets, arguably, masking its discursive and practical configuration that underpins the structural transformations toward neoliberal democracy (Fisher, 2012).

Moreover, in today's context, particularly in urban settings like smart cities, attention is also drawn to terms such as 'algorithmic governance' (Coletta \& Kitchin, 2017; Danaher et al., 2017), 'artificial intelligence governance' (Gasser \& Almeida, 2017), 'Internet of Things governance' (Almeida, Doneda, \& Monteiro, 2018), and 'smart city governance' (Castelnovo et al., 2016). What these terms have in common is that they are deployed to point to the specificities and complexities of certain ICT and governance issues involved. Generally they tend to refer to the underpinning hard- and software, and for which, more commonly the buzzword 'platform' is used to point to a complex configuration of stakeholders and played out, here, in the city. ${ }^{2}$ More specifically, the term platform is often used to carry out discursive work, for example, for so-called platform companies like Google to ambiguously describe their role in the market as well as their services towards users and other

\footnotetext{
${ }^{1}$ See https://www.waze.com

2 Platforms are, arguably, central to the so-called content or media infrastructure of the Internet and is emerging as the distinctive new media industrial form of the digital era. In addition, platforms are said to undergo a process of mediatisation in generating meta-information about the platform as a key part of their (platform) business strategy suggesting that 'non-media' platform organisations start to take after media businesses (Nieborg \& Poell, 2018; Van Couvering, 2017).
} 
stakeholders cutting across sectors, genres and so forth (Gillespie, 2010; Srnicek, 2017). Many definitions can be detected highlighting the term's various connotations (Evans, Hagiu, \& Schmalensee, 2006; Helmond, 2015; Sun, Gregor, \& Keating, 2016; van Dijck, 2013). A focus on medium-specificity can be detected in understanding a digital platform as "a reconfigurable base of compatible components on which firms and users build applications. Applications share the general purpose components, thereby exploiting increasing returns at an industry wide level" (Bresnahan \& Greenstein, 2014, p. 475). Such a definition highlights that sites can be modified or programmed by 3rd parties or other stakeholders, such as through software interfaces. It ignores however the way platform companies may render social computing and with what implications for citizens (Mansell, 2016). Put aptly by Gillespie platforms are:

Sites and services that host public expression, store it on and serve it up from the cloud, organize access to it through search and recommendation, or install it onto mobile devices....What unites them all is their central offer: to host and organize user content for public circulation, without having produced or commissioned it. They don't make the content, but they make important choices about that content: what they will distribute and to whom, how they will connect users and broker their interactions, and what they will refuse. (2010, p. 1)

This understanding corresponds somewhat to what is associated with the term 'multi-sided markets' in the economics and management literature, and where a platform is seen as an enabler of interactions between two or more distinct parties (Rochet \& Tirole, 2003). In this view, users and intermediaries like advertisers are, for example, brought together by Facebook, and can so benefit from network effects (Hagiu, 2014). Platforms thus tend to be understood as 'platforms as markets' or 'platforms as modular technological architectures' (Gawer, 2014).

In this stream of thought, a multifaceted dynamic becomes apparent encapsulating all agents, both private and public, involved in the (e-governance) ecosystem, as 'participants' which is closely linked to what has been termed the Web 2.0 Internet economy and its 'participatory turn' in digital development practices (O'Reilly, 2005). It denotes the convergence of production, distribution, and consumption practices and a combination of creativity, collaboration, sharing-enabled digital technologies related with knowledge-intensive and information-rich user-created content activities (van der Graaf, 2018). Participation has then become an important term in developing a framework to understand how the changing media and communication environment enables or hinders participation in society, in reshaping the 'opportunity structures' by which people can participate in an increasingly mediatized society (Cammaerts, 2012; Livingstone, 2013). Facilitated by accessible and easy-to-use tools for content production and distribution, user participation has since been emerging as a creative infrastructure, where users-though not all, and not equally-actively engage in shaping, altering, and sharing digital content (or, data) and attracting their own publics across complex platforms hosted by digital firms like Instagram that cannot exist without it (van der Graaf \& Ballon, 2018). The processes of participation (and, more widely, of democracy) are thus increasingly shaped by modern digital networked media. Moreover, practices that emerge are said to render cultural production and cultural commodities 'contingent', that is, 'dependent on' a select group of powerful platforms. This further implies that in using platforms, such as Google or Facebook, people trust their personal data to these platform companies. A practice that increasingly also has been taken up by the state or city administrations, such as via city-developed applications and open data and citizen science initiatives to participate in (for example, measuring air quality locally or marking what needs to be fixed or cleaned up in your street), and deployed for social, economic, environmental or political governance purposes (Brown \& Marsden, 2013; van der Graaf \& Veeckman, 2014; Zittrain, 2008). Furthermore, these platform-based products and services are also 'contingent' in that they are modular and malleable facilitating a perpetual stream of input, output, revisions, and recirculation practices, which is no longer bounded by private or public or third sector institutional boundaries. This means that processes at work are indicative of a blending together of dynamics of community and commerce underpinned by trajectories of what increasingly seems to be termed 'platformisation.' Here, the platform is the dominant infrastructural and economic model with centrifugal powers (Helmond, 2015; Nieborg \& Poell, 2018), thereby also introducing all actors involved to new options and challenges that in their turn may impact these trajectories as they materialize (cf. Srnicek, 2017).

Today, while increasingly attention is being directed to this development (in various disciplines, such as business and software studies) insufficient systematic insights are available in its mechanisms and the consequent becoming contingent of cultural, governmental commodities and so forth, fundamentally affecting the operations of e-governance practices and services, and, hence, the smart city imaginary. The idea of participation is not new in this context, but engaging with users is thus an important focal point for private, public and third sector organisations and the 'platform' has become a common type of online organizational form to do so. It highlights the need for multi-sided-based structures to determine the right balance between control and openness, supported by considerable technical infrastructure (van der Graaf \& Ballon, 2018). In this, the role of public institutions and the government has become multifold, namely as user, developer and regulator of platforms, and consequently, demands public scrutiny. What are the trade-offs of investing public money in a com- 
mercial platform or application where data of citizens will be collected and stored? And what if that platform company is a global company? What are the platform arrangements with other intermediaries? How transparent are these? Can platform operators exercise direct control over content? Can they shape citizen's (online) experience in ways that are consistent with optimising their revenues or is that inconsistent with fostering the public interest, such as for example in terms of media plurality? Indeed, a platform urbanism can be seen to emerge which puts the issue of public value forward. Again, the interest in examining public value is not new in the wider context of public administration (Rutgers, 2014). Also, a robust definition of the term or a construct cannot be easily distilled from the literature. However, important elements are aptly captured by "maximising the utility of government to civil society by providing services directed towards the public good" (Rose et al., 2014, p. 540). The operationalization of public value by means of decision-making processes stresses accountability among stakeholders throughout, underpinned by questions of legitimization, political acceptability, feasibility and valuable public outcomes (Moore, 2014; Williams \& Shearer, 2011). In the context of the increasing (private) platform(ised)-supported digital services the delivery of a balanced portfolio of benefits and perceived as such by all stakeholders needs to be sought after, whereby the value of the service-enabling objective should be assessed in terms of the quality of 'public service' and the extent of 'citizen-centricity' (Rose et al., 2014). Studies have shown, however, that "whilst citizens may desire [public value] to be delivered through their digitized services, in practice, the effects of egovernment initiatives are rather different" and, as a result, more research is needed "of electronic governmentenabled [public value] realization, to better understand the relationship between technology, stakeholders and organisational structures" as well as that of co-creation dynamics of public value among governments and user communities (Rawahi et al., 2016, pp. 4-5). In particular, the latter effort also draws attention to the future orientation perspective of e-governance. More specifically, it highlights an emerging interest in the sustainability concept as a response to the current public practice so to optimize "a process of continuously managing conflicts between different values", thereby making constant tradeoffs between social, economic, environmental and technical aspects (Larsson \& Grönlund, 2016, p. 106).

In order to reveal better the rapidly increasing complexity that e-government services and practices are facing in smart cities, particularly in terms of growing numbers of multiple stakeholders and perpetual platformdependency, the next section explores such manifestations on the basis of the social navigation application Waze (Alphabeth Inc./Google). The findings illustrate systemic features of possible platform-based e-governance solutions that need to be carefully examined by aca- demics and regulators so as to not (un/intentionally) counter public value and versions of smart cities design by lack of public oversight and an effective assessment framework.

\section{Waze. Outsmarting Traffic, Together}

In order to explore the current dynamics in e-governance practices materializing between 'commerce and community' associated with an emerging platform urbanism, a single case study approach was selected (Yin, 2003). This exploratory study therefore does not represent a 'sample' but aims to be generalizable to the theoretical propositions. The focus is on the popular social navigation application Waze that caters to several stakeholder groups and plays out on the actual streets of cities (and beyond). The preliminary findings presented within the confines of this study, are part of a larger study on smart mobility in Belgium (van der Graaf \& Ballon, 2018). Here, the narrative is based on document and content analysis of the website of Waze Belgium/Benelux community and its roughly 50.000 users $^{3}$ (Bryman, 2012). What follows first is a short overview of the ins and outs of Waze as well as its systemic features. The aim is thus not to offer an understanding of its success or, for example, how the Waze interface enables participation, or establishes new driving experiences (van der Graaf \& Ballon, 2018). Rather, the scope is to reveal the complex multistakeholder ecosystem of a firm-hosted and platformbased social navigation service that impacts the public sphere, thereby highlighting the interest and challenges for cities and e-governance practices.

In 2006 Waze Mobile Limited released a free open source mapping project called "Freemap Israel", which in 2008 transited into the for-profit company Waze, and in 2013 was bought by Alphabeth Inc. (Google). Today, Waze is purposefully designed navigation software for smartphones and GPS-based tablets which facilitates various stakeholder groups to engage and participate (at different stages and in different capacities) in informationbased development practices impacting wayfinding. As its main features, the application offers turn-by-turn (voice) navigation information, real-time and locationspecific traffic as well as user-generated map data, travel times and route details. As a result, it can provide socalled 'Wazers' (drivers) with the fastest real-time route. Waze also facilitates and encourages Wazers to participate in practices such as reporting accidents, speed and police traps, and the more vested ones can get involved in practices such as editing maps. In this view, criticisms such as from police departments can be detected too, challenging somewhat precarious government relations. Furthermore, the application can be used to connect to other services like Facebook. It has also expanded its services to, among others, carpooling, media partnerships (e.g., traffic reporting), and a data exchange program with cities ('Connected Citizens Program'). In prin-

\footnotetext{
${ }_{3}^{3}$ For more specific stats per city see:: https: //wazebelgium.be/stat/high.php
} 
ciple, Waze can be deployed anywhere but requires sufficient initial users to generate (and update) the maps to make it functional. Presently, 13 countries have a full base map and many more cope with incomplete maps, actively inviting users to participate in recording roads and so forth. Currently, Waze counts about 100 million users worldwide and is available in $50+$ languages, supporting so one of the biggest 'community-based' traffic and navigation application. Its network effect (the more people/data, the better the accuracy of information returns), the fact that it is free of charge, and many participatory and gamified elements may hint to its success (Ramos, 2016). The latter can be seen in, for example, the use of an avatar-based profile: driving, reporting, editing the map will earn users different amounts of points moving up from a 'Baby' avatar to eventually 'Royalty'. The app interface itself shows a virtual map of one's immediate surroundings and shows the location of nearby Wazers allowing for a spatial, temporal and social feel of one's position. Furthermore, the app consists of several features that elaborate one's (personal) information, current location, input for directions, a friend finder and a 'report' menu to give in accidents, traffic jams, police nearby, speed cameras, road hazards, fuel prices, map issues, road hazards, and a social mechanism to take and post pictures of places and chat with other Wazers.

Waze subscribes to the 'participatory turn' with slogans like "Nothing can beat real people working together" and "Partner with Waze". It draws various user groups associated with different modes of engagement, varying from a basic user to a more advanced one (such as developer) to partnerships, facilitated by designated tools. More specifically, Waze discerns between 'Drivers' which are passive users (use app for navigation purposes only, yet their data such as 'speed' is collected); 'Reporters' are more active and contribute input, such as accidents; 'Editors' are the more advanced users and participate in map editing practices (herein 6 editor ranks exist as well and operate like a 'community of practice' supported by an apprentice system (Berdou, 2011). What is the value or benefits that can be distilled among its users? The findings suggest that the main benefit is not navigation from $A$ to $B$ per se but rather lies in its capability to avoid traffic by offering alternative ways, that are often unfamiliar to the user. Not everyone likes this "sight-seeing" element but the app does seem to contribute in this way to emergent forms of spatial awareness and may set new habits and patterns for mobility (cf. van der Graaf \& Ballon, 2018). Moreover, increasingly complaints (also to their city governments) can be heard from people living in residential streets were suddenly a rat race during rush hour can be detected. In addition, for Editors, benefits can be detected, such as aspects of 'enjoyment', 'peer recognition,' 'career advancement' - summed up by a Belgium country manager by "if you get involved enough, the opportunity to help shape the future of Waze." Secondary order benefits include value stemming from among oth- ers shorter transit times, lower gas consumption, playful interface, and its social features (Hind \& Gekker, 2014). The sociability element is mainly reported on by way of seeing others on the interface, rendering an explicit reminder of participation in a collective of drivers which may challenge existing driving theories that tend to focus on anonymity and individuality of the driving experience (Ramirez, 2016). Glitches sometimes show users nearby when in reality there is nobody around which "puts the gamified aspect upfront" and may downplay Waze's realtime data selling-point and overall trust.

The 'work' of Waze is played out on (mostly) public roads, and, hence, cities - that have willingness to innovate and the technical capabilities necessary to share data-represent an important side of Waze's multi-sided market model for which Waze developed a city-facing partnership program, operational from 2014, called Connected Citizens Program. It is advertised as "the Waze Way of free data exchange, yielding actionable insights and improved mobility on a local and global scale" for public institutions world-wide to "take part in the smart solution" on its firm-hosted platform. Furthermore, the term "proof" is deployed to boldly claim that Waze already holds the answer to some mobility challenges by stressing that their platform in this way can expand "from a data-sharing initiative with Waze to a knowledge-sharing platform where they can apply learnings from across the world to their local communities." In stressing the promise of creating shared value in 'private and public (and people) partnership' without financial costs, the partnerships are two-way exchanges of information: at minimum, Waze shares data about traffic jams (collected from drivers) and user-reported traffic issues and partnering governments share information about road closures and other incidents, so helping to optimize route options for drivers. In particular, the CCP program-encompassing around 600 partners-draws on data exchanges between city, state and national governments (such as departments of transportation and mobility, police departments) non-profits and first responders. For example, the city of Ghent (Belgium), for its 'Ghent's Circulation Plan', partnered up to reduce traffic, make the city safer, and improve air quality by 'reshaping' the centre by changing and adding 2,000 road signs (Tilto, 2017; Waze, 2017). The city has reported a $30 \%$ reduction in accidents, $27 \%$ more cyclists, and a $15 \%$ increase in people taking a bus or tram. Note that other companies like TomTom were also contacted to make subsequent changes, as a result. An important benefit for cities to partner up is saving costs and efficiency as it offers a means, for example, to freely expand its view of its roads and streets, but also to come to better insights into, for example, particular congested areas to facilitate "smarter urban planning", yet concerns are raised too, such as about the degrees of anonymity as social navigation tools 'turn' their user base into a "network of sensors". For Waze it is an important way to grow and improve its services and facilitates more accurate inputs to 
complex traffic algorithms, and, city-provided data may help them to stay ahead of crowd-sourced data. More services can also be developed using this information, such as specific routes on trash collection days. In fact, and this goes for all platform companies, the competition to engage and retain users is fierce, partnering up with cities is therefore also an important means to expand and sustain its market penetration. Moreover, as the market for wayfinding and ride-sharing (and pending self-driving cars) is still taking flight, for now, the competitive advantage can be mostly found in the volume and accuracy of traffic data, street data, and so forth. This is facilitated by Waze's set data standards so as to minimize data fragmentation and to better aggregate transport and government data.

\section{Conclusion: A Dialogue of Values}

From the exploratory analysis, a complex ecosystem is surfacing where different commercial, public and communal modalities intersect and interact driven by and impacting on different agendas and values. The argument is that the urban public sphere via a social wayfinding application is becoming more 'platformised' as more sides are introduced to the public sphere of streets as market, especially in the form of the abstraction of data/information production from data/information distribution. Also, the platform has become more 'mediatised' as not only it increasingly stores a layer of metainformation about users and content for resale such as to advertisers, but also it allows for in/direct social interactions via its participatory features. Lastly, a competitive logic to draw in and ensure a critical mass of stakeholders (drivers but also cities) can be distilled not only for the application to become more useful for immediate users (network effect) but also to build up information about the user base to sell on to others. The algorithms at work in this ecosystem operate then to, at minimum, search, display, track and trace, to match and sort (cf. Van Couvering, 2017). As the commercial and global developer firm (and now owned by Google), Waze putsat minimum-pressing issues of (algorithmically-based) control and transparency, or lack thereof, forward raising some rather crucial questions touching upon the very essence of e-governance and the public value promise. A promise that, based on existing literature on the impact of e-government on public value, is not a given, and especially not in a smart city context where the focus has been, thus far, more technocratic than humane (Almeida et al., 2018; Rose et al., 2015).

Critical discussion is called for about who decides which problems merit to partner with global platform companies? How is public spending allocated in this? What are the trade-offs of data wants/needs and how are they exchanged vis-à-vis the corporate and public agendas? What are the objectives of cities in their data aspirations? How to circumvent platform companies or other corporate power to capture the multi-stakeholder trajectory and process? What role to take on, that of performing an operator or an orchestrator role? Or, what is the (power) trajectory of 'platform as governance' vis-à-vis 'government as platform'? How to move from vertical segment thinking to new points of control? Derivative questions are raised too, such as about the future of governmental structures of driving control. Furthermore, the trajectory of platform dependency in this multi-stakeholder and multi-sided market context alludes to government practices and behaviour becoming co-dependent on actors 'elsewhere', where markets and associated e-government products and services connote multiplying, opaqueness and perpetual embeddedness of markets (cf. 'stacking' in Vonderau, 2017). Silo measures of market power or excluding intermediary platform companies from public interest regulation seems no longer a preferred way forward. Achieving these goals demands a balance, but the platform companies are not neutral gatekeepers and also will not become so as a consequence of market dynamics (Mansell, 2016). Economic calculus and citizen use indicators should not be the motivators for a normative consideration of the need for establishing effective smart e-governance services and a vibrant public sphere that is compatible with democratic practice. Thus, these and other tough questions remain if we want to build cities that are truly smart and humane provisioned perhaps as a public good, supporting public values like participation, trust, privacy, inclusivity and diversity.

A critical investigation is thus warranted into, especially, algorithmic regulation and governance structures between the urban and 'platforms' in the context of what is, arguably, considered to be a weakness in understanding today's smart cities framework. That is, how public value can be realized and sustained under the current 'mainstreaming e-government's condition', thereby highlighting and reconsidering seeming dynamic roles and ownerships in 'city making' - to determine whose version it is. The trend of platform-based e-governance solutions, associated with platform urbanism, is thus another black box, and highlights massive information asymmetries between, most notably, the developers of such systems, cities, citizens and policymakers. When considering future e-governance models for platform-based urban ecosystems, it is helpful and necessary to consider some structural challenges associated with the 'regulation' of platforms and which may result in an effective assessment framework for smart cities (cf. Gasser \& Almeida, 2017; Rawahi et al., 2016). Attention therefore needs to shift to platform arrangements and creating an evidence base, allowing the focus the move to new control points.

\section{Acknowledgments}

I would like to thank the reviewers for their fruitful comments on an earlier version of this work. Also, Jan Waeben for his critical eye. 


\section{Conflict of Interests}

The author declares no conflict of interests.

\section{References}

Almeida, V., Doneda, D., \& Monteiro, M. (2018). Governance challenges for the Internet of things. IEEE Computer Society, 19(4), 56-59.

Berdou, E. (2011). Organization in open source communities: At the crossroads of the gift and market economies. New York, NY: Routledge.

Bernardi, M. (2015). Sharing cities. Governance models and collaborative practices in the urban contexts (Unpublished Doctoral dissertation). Università degli Studi di Milano-Bicocca, Italy.

Bresnahan, T., \& Greenstein, S. (2014). Mobile computing: The next platform rivalry. American Economic Review, 104(5), 475-480.

Brown, I., \& Marsden, C. (2013). Regulating code: Good governance and better regulation in the information age. Information revolution and global politics. Cambridge, MA: MIT Press.

Bryant, A. (2007). Government, e-government, and modernity. In D. Griffin, P. Trevorrow, \& E. Halpin (Eds.), Developments in e-government: A critical analysis (pp. 3-15). Amsterdam: IOS Press.

Bryman, A. (2012). Social research methods (4th ed.). Oxford: Oxford University Press.

Cammaerts, B. (2012). Protest logics and the mediation opportunity structure. European Journal of Communication, 27(2), 117-134.

Caplan, R., \& boyd, D. (2016). Who controls the public sphere in an era of algorithms? Mediation, automation, power. Data \& Society. Retrieved from https:// datasociety.net/pubs/ap/MediationAutomationPower 2016.pdf

Castelnovo, W., Misuraca, G., \& Savoldelli, A. (2016). Smart cities governance: The need for a holistic approach to assessing urban participatory policy making. Social Science Computer Review, 34(6), 724-739.

Coletta, C., \& Kitchin, R. (2017). Algorhythmic governance: Regulating the 'heartbeat' of a city using the Internet of Things. Big Data \& Society. doi:10.1177/ 2053951717742418

Danaher, J., Hogan, M. J., Noone, C., Kennedy, R., Behan, A., De Paor, A., . . . Shankar, K. (2017). Algorithmic governance: Developing a research agenda through the power of collective intelligence. Big Data and Society, 4(2), 1-21. doi:10.1177/2053951717726554

Driscoll, K. (2016). Cloudy with a chance of dystopia: Tung-Hui Hu's "a prehistory of the cloud". Los Angeles Review of Books. Retrieved from https:// lareviewofbooks.org/article/cloudy-with-a-chanceof-dystopia-tung-hui-hus-a-prehistory-of-the-cloud

Evans, D. S., Hagiu, A., \& Schmalensee, R. (2006). Invisible engines: How software platforms drive innovation and transform industries. Cambridge, MA: MIT
Press.

Finn, E. (2017). What algorithms want. Imagination in the age of computing. Cambridge, MA: MIT Press.

Fisher, E. (2012). E-governance and e-democracy: Questioning technology-centered categories. In D. LeviFaur (Ed.), Oxford handbook of governance ( $p p$. 569-583). Oxford: Oxford University Press.

Gasser, U., \& Almeida, V. (2017). A layered model for Al governance. IEEE Computer Society, 21(6), 58-62.

Gawer, A. (2014). Bridging differing perspectives on technological platforms: Toward an integrative framework. Research Policy, 43, 1239-1249. doi:10.1016/ j.respol.2014.03.006

Georgiou, M. (2010). Media and the city: Making sense of place. International Journal of Media and Cultural Politics, 6(3), 343-350.

Gillespie, T. (2010). Politics of "platforms". New Media \& Society, 12, 347-364. doi:10.1177/ 1461444809342738

Gillespie, T. (2018). Regulation of and by platforms. In J. Burgess, A. Marwick, \& T. Poell (Eds.), The Sage handbook of social media (pp. 254-278). London: SAGE.

Habermas, J. (1991). The structural transformation of the public sphere: An inquiry into a category of bourgeois society. Cambridge, MA: MIT Press.

Hagiu, A. (2014). Strategic decisions for multisided platforms. MIT Sloan Management Review, 55, 71-80.

Helmond, A. (2015). The platformization of the web: Making web data platform ready. Social Media + Society, 1(11). doi:10.1177/2056305115603080

Hind, S., \& Gekker, A. (2014). Outsmarting traffic, together: Driving as social navigation exchanges. Warwick Research Journal, 1(2). doi:10.31273/ eirj.v1i2.84

Hu, T.-H. (2016). A prehistory of the cloud. Cambridge, MA: MIT Press.

Janowski, T. (2015). Digital government evolution: From transformation to contextualization. Government Information Quarterly, 32(3), 221-236.

Janowski, T. (2016). Implementing sustainable development goals with digital government-Aspirationcapacity gap. Government Information Quarterly, 33, 603-613.

Jenkins, H. (2006). Convergence culture: Where old and new media collide. New York, NY: New York University Press.

Kitchin, R., \& Dodge, M. (2011). Code/space: Software and everyday life. Cambridge, MA: MIT Press.

Komninos, N., \& Mora, L. (2018). Exploring the big picture of smart city research. Science Regionale-The Italian Journal of Regional Science. doi:10.14650/ 88815

Larsson, H., \& Grönlund, Å. (2016). Sustainable egovernance? Practices, problems and beliefs about the future in Swedish egov practice. Government Information Quarterly, 33(1), 105-114.

Livingstone, S. (2013) The participation paradigm in audience research. Communication Review, 16(1/2), 
21-30. doi:10.1080/10714421.2013.757174

Mansell, R. (2016). Unpacking black boxes: Understanding digital platform innovation. Draft Information, Communication and Society (Unpuplished research paper). London: London School of Economics and Political Science. Retrieved from https://www. academia.edu/30175620/Unpacking_Black_Boxes_ Understanding_Digital_Platform_Innovation

Mattern, S. (2017). Code + clay... data + dirt. Minneapolis: University of Minnesota Press.

Meijer, A., \& Bekkers, V. (2015). A metatheory of egovernment: Creating some order in a fragmented research field. Government Information Quarterly, 32(3), 237-245.

Moore, M. (2014). Public value accounting: Establishing the philosophical basis. Public Administration Review, 74(4), 465-477.

Nieborg, D. B., \& Poell, T. (2018). The platformization of cultural production: Theorizing the contingent cultural commodity. New Media \& Society. doi:10.1177/ 1461444818769694

Nugent, J. (2001). If e-democracy is the answer, what's the question? National Civic Review, 90, 221-233.

O'Reilly, T. (2005, November 30). What is web 2.0. Design Patterns and Business Models for the Next Generation of Software. O'Reilly. Retrieved from http:// www.oreillynet.com /pub/a/oreilly/tim/news/2005/ 09/30/what-is-web-20.html

Overton, D. (2017). Next generation internet initiative (Consultation final report). Brussels: European Commission. Retrieved from https://ec.europa.eu/ futurium/en/system/files/ged/ec_ngi_final_report_1. pdf

Ramirez, R. (2016). Spatial practices/digital traces: Embodiment and reconfigurations of urban spaces through GPS mobile applications (Unpublished Doctoral dissertation). The Bartlett School of Architecture, University College London, UK.

Ramos, R. (2016). Driving screens: Space, time, and embodiment in the use of Waze. In C. Travis \& A. von Lünen (Eds.), The digital arts and humanities (pp. 139-150). Basel: Springer International Publishing Switzerland.

Rawahi, A., Coombs, K., \& Doherty, N. (2016). The realization of public value through e-government: A structuration perspective. In Proceedings of the 37th international conference on information systems (ICIS 2016). Dublin, Ireland. Retrieved from https:// dspace.lboro.ac.uk/dspace-jspui/bitstream/2134/23 697/1/Al\%20Rawahi\%20et\%20al\%20\%282016\%29.pdf

Rochet, J.-C., \& Tirole, J. (2003). Platform competition in two-sided markets. Journal of the European Economic Association, 1, 990-1029. doi:10.1162/ 154247603322493212

Rose, J., Persson, J., \& Heeager, L. (2015). How egovernment managers prioritise rival value positions: The efficiency imperative. Information Policy, 20(1), 35-59.
Rose, J., Persson, J., Heeager, L., \& Irani, Z. (2014). Managing e-government: Value positions and relationships. Info Systems Journal, 25(5), 531-571.

Rutgers, M. (2014). As good as it gets? On the meaning of public value in the study of policy and management. The American Review of Public Administration, 45(1), 29-45.

Savoldelli, A., Codagnone, C., \& Misuraca, G. (2014). Understanding the e-government paradox: Learning from literature and practice on barriers to adoption. Government Information Quarterly, 31, S63-S71.

Srnicek, N. (2017). Platform capitalism. Cambridge: Polity Press.

Sun, R., Gregor, S., \& Keating, B. (2016). Information technology platforms: Conceptualisation and a review of emerging research in IS research. In Australasian conference on information systems Proceedings (pp. 1-17). Adelaide, Australia. Retrieved from: https:// arxiv.org/ftp/arxiv/papers/1606/1606.01445.pdf ISBN: 978-0-646-95337-3

Tilto. (2017). Waze is klaar voor het Circulatieplan van Gent [Waze is ready for Ghent's Circulation Plan]. Waze Belgium. Retrieved from https://www.waze belgium.be/waze-is-klaar-voor-het-circulatieplan-van -gent

United Nations. (2014). UN e-government survey 2014. E-government for the future we want. New York, NY: UNPAN. Retrieved from http://unpan3.un.org/ egovkb/Portals/egovkb/Documents/un/2014-Survey /E-Gov_Complete_Survey-2014.pdf

Van Couvering, E. (2017). The political economy of new media revisited: Platformisation, mediatisation, and the politics of algorithms. In Proceedings of the 50th Hawaii international conference on system sciences (pp. 1812-1819). Retrieved from http://hdl.handle. net/10125/41374

van der Graaf, S. (2018). ComMODify! User creativity at the intersection of commerce and community. Cham: Palgrave MacMillan.

van der Graaf, S., \& Veeckman, C. (2014). Designing for participatory governance: Assessing capabilities and toolkits in public service delivery. Info: The Journal of Policy, Regulation and Strategy for Telecommunications, Information and Media, 16(6), 74-88.

van der Graaf, S., \& Ballon, P. (2018). Navigating platform urbanism. Technological Forecasting and Social Change. doi:10.1016/j.techfore.2018.07.027

van Dijck, J. (2013). The culture of connectivity. A critical history of social media. Oxford: Oxford University Press.

van Dijck, J., Poell, T., \& De Waal, M. (2016). De platformsamenleving: Strijd om publieke waarden in een online wereld [The platform society: a struggle for public value in an online world]. Amsterdam: Amsterdam University Press.

Vonderau, P. (2017). The Spotify effect: Digital distribution and financial growth. Television and New Media. doi:10.1177/1527476417741200 
Waze. (2017). Reducing traffic in Ghent city center. Waze. Retrieved from https://www.waze.com/en-GB/ccp/ casestudies/reducing_traffic_in_ghent_city_center

Williams, I., \& Shearer, H. (2011). Appraising public value: Past, present and futures. Public Administration, 89(4), 1367-1384.

Yin, R. K. (2003). Case study research: Design and methods (3rd ed.). London: Sage.
Zambonelli, F., Salim, F., Loke, S., De Meuter, W., \& Kanhere, S. (2018). Algorithmic governance in smart cities: The conundrum and the potential of pervasive computing solutions. IEEE Technology and Society Magazine, 37(2), 80-87. doi:10.1109/ MTS.2018.2826080

Zittrain, J. (2008). The future of the internet and how to stop it. New Haven, CT: Yale University Press.

\section{About the Author}

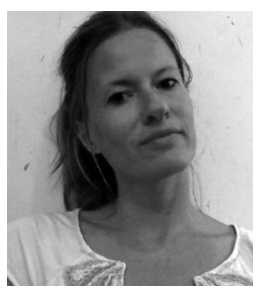

Shenja van der Graaf (PhD, LSE 2009) is a Senior Researcher, heading the strategic and innovative cluster 'Smart Cities' at imec-SMIT, Vrije Universiteit Brussel (Belgium). Her current work is concerned with social, economic, and policy issues arising from innovations associated with the ICTs. Specific lines of inquiry include the integration and management of technological innovation in firms, cities and communities and (new) media users and 'cultures of expertise.' More recently, the focus is on understanding the socio-economic implications of $\mathrm{Al}$, citizen behavior and the governance of public space. 